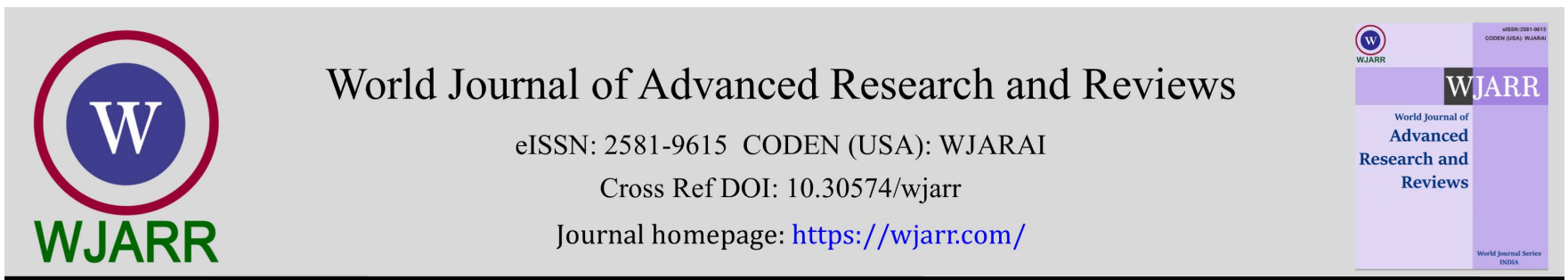

(RESEARCH ARTICLE)

Check for updates

\title{
Analysis of production capacity planning to meet the consumer request using the Rough Cut Capacity Planning (RCCP) method in PT. Maccon Generasi Mandiri Makassar, Indonesia
}

\author{
Lamatinulu *, Ahmad Fadhil, Nurhayati Rauf and Suraidah \\ Department of Industrial Engineering, Faculty of Industrial Technology, Universitas Muslim Indonesia.
}

World Journal of Advanced Research and Reviews, 2021, 12(02), 510-517

Publication history: Received on 20 October 2021; revised on 22 November 2021; accepted on 24 November 2021

Article DOI: https://doi.org/10.30574/wjarr.2021.12.2.0645

\begin{abstract}
Maccon Generasi Mandiri Makassar company is one of a manufacturing company engaged in the production of light brick AAC (Autoclaved Aerated Concrete). PT. Maccon Generasi Mandiri Makassar has a production capacity of 15024 $\mathrm{m}^{3}$ in a month or $180288 \mathrm{~m}^{3}$ in a year. However, with this capacity, the company is often unable to meet high consumer demand of $181450 \mathrm{~m}^{3}$ in a year due to less than optimal engine performance, a number of hours of work and an unbalanced workforce in the producing light brick of ACC (Autoclaved Aerated Concrete). This requires the company to plan the optimal production of capacity in order to fulfill the consumer demand in a timely and appropriate amount so that the expected of company profits will be increased. The purpose of this research is to plan production capacity in the future based on the demand rate of the consumer using the Rough Cut Capacity Planning (RCCP) with the method is Bill of Labor Approach (BOLA) technique. Based on the data processing which has been done, the recommended made were a combination of engine additions and working time. This is realized to fulfill the lack of production capacity. For the January Period = 19872 hours $/$ month, February = 19008 hours $/$ month, March = 19872 hours $/$ month, April = 19008 hours $/$ month, May = 18144 hours $/$ month, June = 18144 hours $/$ month, July = 19872 hour $/$ month, August = 18144 hours $/$ month, September $=17280$ hours $/$ month, October $=18144$ hours $/$ month, November $=18144$ hours $/ \mathrm{month}$, December $=17280$ hours $/$ month.
\end{abstract}

Keywords: Production schedule; Capacity planning; Light brick; RCCP; Bill of Labor

\section{Introduction}

The capacity of the maximum capability of a system or production unit to complete a work target. Knowing the optimal production unit capacity will benefit its application. Production capacity that can be produced within a certain period of time is using available resources [1]. Production capacity planning is the process of selecting resource requirements such as machine, labor in accordance with the company production planning [2].

Maccon Generasi Mandiri Makassar company is one of a manufacturing company engaged in the production of light brick AAC (Autoclaved Aerated Concrete) with the brand Maccon AAC (MAC). Maccon Generation Mandiri company conducts the production process using a mixer machine, which functions to mix cement, silica sand, lime, water, and some additives. Then put into the molding machine (mold). after being cut using a vertical shaped cutting machine measuring $20 \mathrm{~cm}$ and horizontal $60 \mathrm{~cm}$ and thickness $10 \mathrm{~cm}$. After that, the oven was conducted by using an autoclave machine. With this process, the company is able to produce brick with a production capacity of $72 \mathrm{~m}^{3} / \mathrm{hours}$. PT. Maccon Generasi Mandiri Makassar has a production capacity of $180288 \mathrm{~m}^{3} /$ year. But with that capacity, this company

\footnotetext{
${ }^{*}$ Corresponding author: Lamatinulu

Department of Industrial Engineering, Faculty of Industrial Technology, Universitas Muslim Indonesia.

Copyright (C) 2021 Author(s) retain the copyright of this article. This article is published under the terms of the Creative Commons Attribution Liscense 4.0.
} 
often does not meet high consumer demand of $181450 \mathrm{~m}^{3} /$ year. Because it lacks optimal machine performance, the number of hours worked and labor is not balanced in producing light bricks ACC (Autoclaved Aerated Concrete).

Based on the background, for that, I conducted a production capacity planning analysis study of the consumer demand by using the Rough Cut Capacity Planning (RCCP) method at Maccon Generasi Mandiri Makassar company, in the hope that the company can make the right production planning can meet consumer demand.

\section{Methodology}

\subsection{Time and Place of Research}

The place of research in this writing is done in PT Maccon Generasi Mandiri Indonesia located in JL. Pangeran Diponegoro No. 95 AF, Makassar, South Sulawesi. The research was conducted in January 2019. The time of research is for one month.

\subsubsection{Type and Sources of Data}

Data used in this research is quantitative data, that is data obtained directly from PT Maccon Generasi Mandiri Makassar is a data on the number of work stations, labor, working hours, demand data, and time of each work station process.

\subsubsection{Data Source}

The data used in this study are as follows:

- Primary data, the results of data processing that have been carried out in this study are standard time data, forecasting data, master production schedule data, capacity data available, and required data capacity.

- Secondary data, ie data obtained from the documents and materials related reports or closely associated with this research namely production data PT. Maccon Generasi Mandiri Makassar.

\subsection{Method of Collecting Data}

Methods of data collection in the research are as follows:

Field research

- Observation of data collection is done by observing the object observed on PT. Maccon Generasi Mandiri Makassar on the production department.

- Interviews of data collection by conducting a question and answer directly to the production department staff PT. Maccon Generasi Mandiri Makassar.

\subsection{Approach to Research Methods}

The method used in this study is the Rough Cut Capacity Planning (RCCP) method with a Bill Of Labour Approach (BOLA) technique. Rough Cut Capacity Planning (RCCP) is a method is a plan to test the availability of production capacity available in the Master Production Schedule (MPS) [3, 4,5]. Bill of Labour Approach (BOLA) technic is the number of needs needed by multiplying the time matrix with the production matrix [6]. The data needed is:

- Determination of MPS

- Determination of matrices namely standard time matrix and production matrix

- $\quad$ RCCP $=$ (Time Matrix) $x$ (Productions Matrix)

\section{Results and discussion}

The Product Used In This Research Is Light Brick Aac (Autoclaved Aerated Concrete) With The Maccon Brand AAC (MAC). Through 3 work stations namely Mixer, Cutting Machine, and Autoclave Machine.

Before data processing, data collection is carried out first such as time data for each work station, data on the number of working days, data on the number of hours worked, data on the number of workers and product demand data in January-December. The data used in this study are data on the number of workers as shown in Table 1, data for List of Working Hours as in Table 2 and data for Light Brick demand as shown in Table 3. 
Table 1 Data Number of Labour

\begin{tabular}{|l|l|c|}
\hline No & Work Centre & Labour \\
\hline 1 & Mixer & 12 \\
\hline 2 & Cutting & 12 \\
\hline 3 & Autoclave & 9 \\
\hline \multicolumn{2}{|l|}{ Total } & 33 \\
\hline
\end{tabular}

Table 2 List of Working Hours

\begin{tabular}{|c|c|c|}
\hline Shift & $\begin{array}{c}\text { Working Hours } \\
\text { (Jam) }\end{array}$ & $\begin{array}{l}\text { Break } \\
\text { (Jam) }\end{array}$ \\
\hline \multirow{6}{*}{ Morning } & $08.00-12.00$ & \multirow{6}{*}{$12.00-13.00$} \\
\hline & $13.00-16.00$ & \\
\hline & $13.00-15.00$ & \\
\hline & $13.00-16.00$ & \\
\hline & $21.00-24.00$ & \\
\hline & $19.00-23.00$ & \\
\hline \multirow{3}{*}{ Afternoon } & $16.00-20.00$ & \multirow{3}{*}{$20.00-21.00$} \\
\hline & $05.00-08.00$ & \\
\hline & $21.00-24.00$ & \\
\hline \multirow{2}{*}{ Night } & $00.00-04.00$ & \multirow{2}{*}{$04.00-05.00$} \\
\hline & $05.00-08.00$ & \\
\hline
\end{tabular}

Table 3 Light Brick Demand Data

\begin{tabular}{|l|c|c|}
\hline Period 2018 & Month & Demand (unit) \\
\hline 1 & January & 16800 \\
\hline 2 & February & 15600 \\
\hline 3 & March & 14850 \\
\hline 4 & April & 16200 \\
\hline 5 & May & 15900 \\
\hline 6 & June & 16100 \\
\hline 7 & July & 14300 \\
\hline 8 & August & 13400 \\
\hline 9 & September & 13000 \\
\hline 10 & October & 14200 \\
\hline 11 & November & 15400 \\
\hline 12 & December & 15700 \\
\hline \multicolumn{2}{|l|}{ Total } & 181450 \\
\hline
\end{tabular}

The data on labor time at the Work Center (WC) is 10 minutes on the WC Mixer, 8 minutes on the WC Cutting and 240 minutes on the WC Autoclave. 


\subsection{Calculating the standard time of each work station}

For calculation of cycle time measurement, normal time and standard time of each production process taken from the average time of each production process of each work station carried out by the company, the production process includes the process of Mixer, Cutting, and Autoclave. The results of the calculation of the standard time for each work station obtained the standard time at the Mixer work station $=19$ minutes, the cutting work station $=9.57$ minutes and the Autoclave work station $=47.85$ minutes

\subsection{Forecasting}

Forecasting is the process of estimating future needs in a period of time by looking at the level of consumer demand for a product [7]. Where in this study the demand data was taken from January to December 2018 which was obtained directly from the company. Based on the results of data processing with the Linear Regression forecasting method using the POM-QM software application for windows as attached, then get the forecasting results as in Table 4.

Table 4 Light Brick Forecasting Data

\begin{tabular}{|c|l|c|c|l|c|}
\hline Period & Month & Forecasting (unit) & Period & Month & Forecasting (unit) \\
\hline 1 & January & 15963 & 7 & July & 15045 \\
\hline 2 & February & 15810 & 8 & August & 14892 \\
\hline 3 & March & 15657 & 9 & September & 14739 \\
\hline 4 & April & 15504 & 10 & October & 14586 \\
\hline 5 & May & 15351 & 11 & November & 14433 \\
\hline 6 & June & 15198 & 12 & December & 14280 \\
\hline \multicolumn{7}{|c|}{ The number of forecasting results from January to December = 181458 } \\
\hline
\end{tabular}

\subsection{Master Productions Schedule}

The master production schedule is a production plan using the relationship between the quantity of each type of product at a certain period $[8,9]$. The details are as follows:

Gross needs are taken from the results of the demand request from January to December 2018.

- $\quad \mathrm{POH}^{*}$ (Project on Hand), namely inventory owned

- $\quad$ The initial POH is 0 units

- $\quad$ Net needs are obtained from gross needs minus POH. And can be seen in table 5.

Table 5 Master Production Schedule

\begin{tabular}{|c|c|c|c|}
\hline Month & Gross Needs (Unit) & POH $^{*}$ & Net \\
\hline January & 15963 & 0 & 15963 \\
\hline February & 15810 & 0 & 15810 \\
\hline March & 15657 & 0 & 15657 \\
\hline April & 15504 & 0 & 15504 \\
\hline May & 15351 & 0 & 15351 \\
\hline June & 15198 & 0 & 15198 \\
\hline July & 15045 & 0 & 15045 \\
\hline August & 14892 & 0 & 14892 \\
\hline September & 14739 & 0 & 14739 \\
\hline October & 14586 & 0 & 14586 \\
\hline November & 14433 & 0 & 14433 \\
\hline December & 14280 & 0 & 14280 \\
\hline
\end{tabular}




\subsection{Production Matrix}

The demand production matrix is obtained from the results of net needs on the Master Production Schedule (MPS), where the results of the production schedule are obtained from the sum of the gross needs (units) with POH (Projects in Hand) which is needed or purchased. Can be seen in Table 6.

Table 6 Master Production Schedule

\begin{tabular}{|c|c|c|c|}
\hline Period & Light Brich (Unit) & Period & Light Brich (Unit) \\
\hline January & 15963 & July & 15045 \\
\hline February & 15810 & August & 14892 \\
\hline March & 15657 & September & 14739 \\
\hline April & 15504 & October & 14586 \\
\hline May & 15351 & November & 14433 \\
\hline June & 15198 & December & 14280 \\
\hline
\end{tabular}

\subsection{Standardd Time Matrix}

The standard time matrix is the results of the standard time of each work station or in the production process, namely the process of Mixer, Cutting and Autoclave. The description of the standard time matrix is as in Table 7.

Table 7 Standard Time Matrix

\begin{tabular}{|c|l|c|c|}
\hline No & $\begin{array}{c}\text { Work } \\
\text { Centre }\end{array}$ & $\begin{array}{c}\text { Standart Time } \\
\text { (Minute) }\end{array}$ & $\begin{array}{c}\text { Standart Time } \\
\text { (hours) }\end{array}$ \\
\hline 1 & Mixer & 11,94 & 0,999 \\
\hline 2 & Cutting & 9,57 & 0,159 \\
\hline 3 & Autoclave & 47,85 & 0,797 \\
\hline
\end{tabular}

\subsection{Available Production Time}

In this study, a calculation analysis was also carried out to determine the available capacity as shown in Table 8 .

Table 8 Capacity Available

\begin{tabular}{|c|c|c|c|c|}
\hline Period & Mixer & Cutting & Autoclave & ICapacity Available \\
\hline 1 & 5796 & 5796 & 4347 & 15939 \\
\hline 2 & 5544 & 5544 & 4158 & 15246 \\
\hline 3 & 5796 & 5796 & 4347 & 15939 \\
\hline 4 & 5544 & 5544 & 4158 & 15246 \\
\hline 5 & 5292 & 5292 & 3969 & 14553 \\
\hline 6 & 5292 & 5292 & 3969 & 14553 \\
\hline 7 & 5796 & 5796 & 4347 & 15939 \\
\hline 8 & 5292 & 5292 & 3969 & 14553 \\
\hline 9 & 5040 & 5040 & 3780 & 13860 \\
\hline 10 & 5292 & 5292 & 3969 & 14553 \\
\hline 11 & 5292 & 5292 & 3969 & 14553 \\
\hline 12 & 5040 & 5040 & 3780 & 13860 \\
\hline
\end{tabular}


Available production time is used for the production time needed and the production available [10,11]. Management determines in one year production time is available 258 days, in one day as many as 21 working hours.

TPA= NW $\times$ WH $\times$ WD $\times$ UT $\times$ EF

Where: TPA = Production time available; NW= Number of working; WD= Working day;

UT=Utilization; EF=Efficiency

\subsection{Production Time Planning with Rough Cut Capacity Planning (RCCP) Method}

RCCP is planning capacity requirements to test the feasibility of production master schedules [12]. For the Rough Cut Capacity Planning method with the Bill of Labor Approach (BOLA) technique, standard time data (hours) are needed in the light brick production process. Furthermore, the total capacity needed to produce light brick per month is to multiply the production matrix with the standard time matrix (hours) [6].

Example of calculating the capacity requirements of each machine in July 2018, namely:

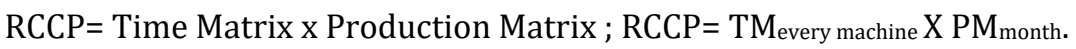

Based on the above formulation, the capacity requirements can be determined as shown in Table 9 .

Table 9 Capacity Needed

\begin{tabular}{|c|c|c|c|c|}
\hline Per-2019 & Mixer & Cutting & Autoclave & $\boldsymbol{\Sigma}$ Capacity Required \\
\hline 1 & 3286 & 2625 & 13159 & 19070 \\
\hline 2 & 3213 & 2567 & 12869 & 18650 \\
\hline 3 & 3141 & 2509 & 12578 & 18228 \\
\hline 4 & 3068 & 2451 & 12287 & 17807 \\
\hline 5 & 2995 & 2393 & 11996 & 17385 \\
\hline 6 & 2923 & 2335 & 11706 & 16963 \\
\hline 7 & 2850 & 2277 & 11415 & 16542 \\
\hline 8 & 2777 & 2219 & 11124 & 16120 \\
\hline 9 & 2705 & 2161 & 10834 & 15700 \\
\hline 10 & 2632 & 2103 & 10543 & 15278 \\
\hline 11 & 2560 & 2045 & 10252 & 14857 \\
\hline 12 & 2487 & 1987 & 10200 & 14674 \\
\hline
\end{tabular}

\subsection{Proposed Production Capacity Planning}

Production Capacity Planning the recommended made were a combination of engine additions and working time. In this alternative, there will also be an additional three employees from the initial labor.

January Period = Working Day x Working Hours x Labor

The following is a comparison between the capacity required (CR) and the capacity available (CA) after the Machine and Working Hours as shown in Table 10.

From graph 1. It can be seen that after planning production capacity with the addition of machinery and working hours there is no longer a lack of production capacity, meaning that the available capacity can be met for each period. 
Table 10 Comparison of Capacity Available and Capacity Required

\begin{tabular}{|c|c|c|}
\hline Period & $\sum$ Capacity Available (Hour) & ¿Capacity Required (Hour) \\
\hline 1 & 19872 & 19070 \\
\hline 2 & 19008 & 18650 \\
\hline 3 & 19872 & 18228 \\
\hline 4 & 19008 & 17807 \\
\hline 5 & 18144 & 17385 \\
\hline 6 & 18144 & 16963 \\
\hline 7 & 19872 & 16542 \\
\hline 8 & 18144 & 16120 \\
\hline 9 & 17280 & 15700 \\
\hline 10 & 18144 & 15278 \\
\hline 11 & 18144 & 14936 \\
\hline 12 & 17280 & 14674 \\
\hline
\end{tabular}

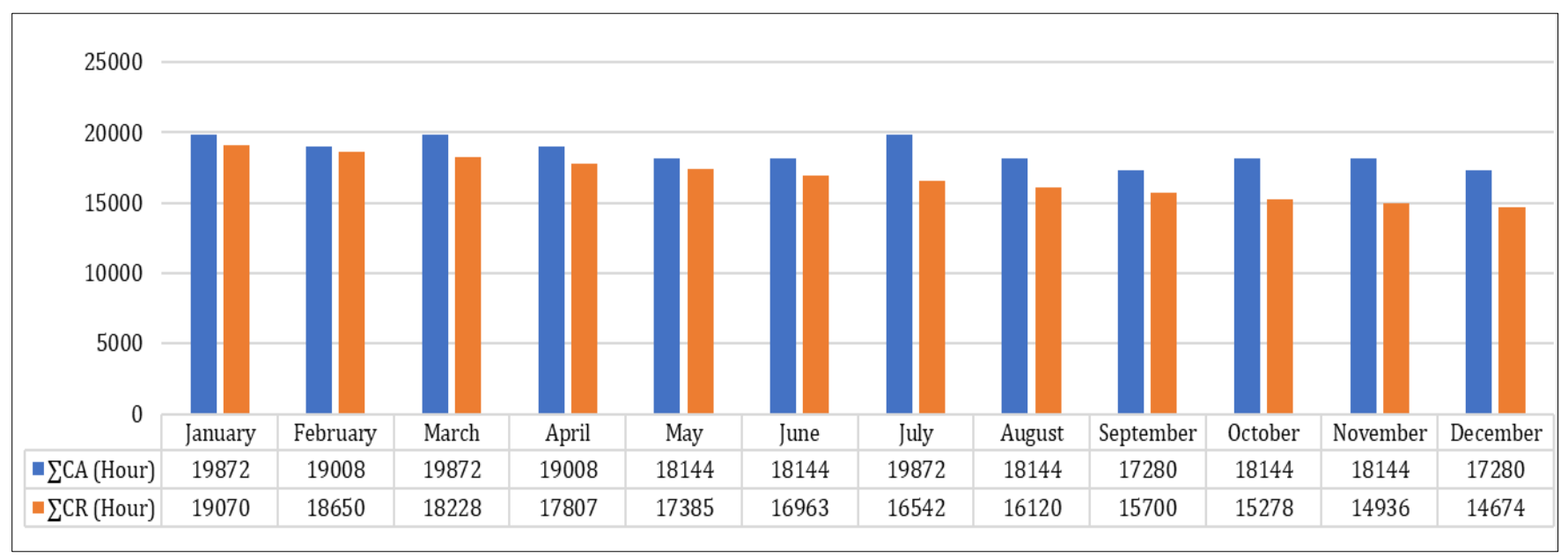

Figure 1 Comparison of available capacity and required capacity after machine addition and working hours

\section{Conclusion}

From the results of data processing, conclusions can be drawn as follows that based on the results of the production capacity planning analysis using the Rough Cut Capacity Planning (RCCP) method with a Bill of Labor Approach (BOLA) technique. Based on the data processing which has been done, to planning production capacity in the future based on the pace of consumer demand that is the recommended made were a combination of engine additions and working time. This is realized to fulfill the lack of production capacity. For the January Period $=19872$ hours $/$ month, February $=$ 19008 hours / month, March $=19872$ hours / month, April = 19008 hours / month, May = 18144 hours $/$ month, June $=18144$ hours $/$ month, July $=19872$ hour $/$ month, August $=18144$ hours $/$ month, September $=17280$ hours $/$ month, October $=18144$ hours $/$ month, November $=18144$ hours $/$ month, December $=17280$ hours $/$ month .

\section{Recommendations}

Suggestions for this research are to support the optimal production plan for the company then suggestions that might benefit the company for the future are by adding machines and increasing working hours because if it is only done by adding machines, it will cost a lot. 


\section{Compliance with ethical standards}

\section{Acknowledgments}

The author's gratitude goes to the Department of Industrial Engineering, Muslim University of Indonesia and the company that has provided support in the smooth implementation of this research.

\section{Disclosure of conflict of interest}

In writing this scientific article, all authors do not have a conflict of interest.

\section{References}

[1] Feasibility of Production Capacity Using Rough Cut Capacity (RCCP) Method In Ppm\#6 Section, PT. Indah Kiat Pulp and Paper, Tbk. Surya Teknika. 2019; 6(1): 1-7.

[2] Sugarindra M, Nurdiansyah R. Production Capacity Optimization with Rough Cut Capacity Planning (RCCP). IOP Conference Series: Materials Science and Engineering. 2020; 722: 012046.

[3] Baroto T. Production Planning and Control. Jakarta; Ghalia Indonesia. 2002.

[4] Jawahar BA, Raja GK. Decision Support System (DSS) for Capacity Planning: A Case Study. International Journal of Advance Research in Computer Science and Management Studies. 2013; 1(4): 24-30.

[5] Najy JR. Cut Capacity Planning-(RCCP)-(Case Study). Advances in Theoretical and Applied Mechanics. 2014; 7(2): $53-66$.

[6] Irawan I, Nasiatin T, Adha S, Julyanto O, Rani CP, \& Dimas PKR. Analysis Of Production Capacity Planning and Control in PT. Krakatau Wajatama with Rought Cut Capacity Planning (RCCP). Journal of Industrial Engineering \& Management Research. 2020; 1(2): 207-218.

[7] Gaspersz, Vincent. Production Planning and Inventory Control. Jakarta; Gramedia. 2004.

[8] Kusuma, Hendra. Production Management, Production Planning and Control. Yogyakarta; Andi. 2004.

[9] Najafian N, Lotfi MM. Evaluating alternative MPS development methods using MCDM and numerical simulation. Journal of Industrial and Systems Engineering. 2017; 10: 73-90.

[10] Handoko TH. Production and Operations Management Fundamentals. Yogyakarta; Fakultas Ekonomi, Univrsitas Gajah Mada. 2008.

[11] Nasution, Hakim. Production Planning and Control. Yogyakarta: Graha Ilmu. 2006.

[12] Sinulingga, Sukaria. Production Planning and Control. Yogyakarta: Graha Ilmu. 2009. 